\title{
Minimally-invasive Right Hepatectomy for Perihilar Cholangiocarcinoma
}

\author{
Francesca Ratti ${ }^{\star}$, Federica Cipriani, Yongha Lee, Rebecca Marino, Marco Catena, Luca Aldrighetti \\ Hepatobiliary Surgery Division, Ospedale San Raffaele, Via Olgettina 60, Milano, Italy
}

\author{
*Corresponding author: \\ Francesca Ratti, M.D. \\ Hepatobiliary Surgery Division \\ Ospedale San Raffaele \\ Via Olgettina 60, Milano, Italy \\ Phone: + 383482411961 \\ $+390226437808$ \\ Fax: $\quad+390226437807$ \\ E-mail: ratti.francesca@hsr.it
}

\begin{abstract}
Rezumat
Hepatectomie dreaptă minim invazivă pentru colangiocarcinom perihilar

Magnificarea imaginilor oferite de chirurgia minim invazivă permite o disecție foarte clară şi precisă a hilului hepatic, permițând depăşirea complexității tehnice a intervenției chirurgicale a colangiocarcinomului perihilar. Recent, au fost raportate fezabilitatea şi reproductibilitatea chirurgiei minim invazive pentru colangiocarcinom perihilar: în centrele cu expertiză adecvată şi respectând principiile oncologice, oferă avantaje pe termen scurt într-o populatiie selectată de pacienți. Videoclipul prezinta cazul unui pacient cu colangiocarcinom perihilar care implică ductul biliar drept şi care a necesitat hepatectomie dreaptă in bloc cu confluența biliară şi rezecție segment 1, cu limfadenectomie asociată. Dovezile actuale, împreună cu fezabilitatea şi reproductibilitatea tehnicii prezentate în acest videoclip, par promițătoare şi constituie o condiție prealabilă bună pentru implementarea ulterioară a acestei abordări pentru a îmbunătăți rezultatul pacienților, respectând în acelaşi timp principiile oncologice chirurgicale în colangiocarcinomul hilar.
\end{abstract}

Cuvinte cheie: hepatectomie dreaptă, colangiocarcinom perihilar

\section{Abstract}

The magnification of images provided by minimally-invasive surgery (MIS) allows a very sharp and precise dissection of the hepatic hilum, allowing to overcome the technical complexity of surgery of perihilar cholangiocarcinoma (PHC). Recently, the feasibility and reproducibility of MIS for PHC are reported: within 
centers with adequate expertise and respecting the cornerstones of oncological adequacy, it provides short term advantages in a selected population of patients. The video reports the case of a patient with PHC involving the right biliary duct and requiring right hepatectomy with biliary confluence and segment 1 resection, with associated lymphadenectomy. Current evidences, together with feasibility and reproducibility of the technique shown in this video, appear promising and constitute a good prerequisite for the further implementation of this approach to improve patients outcome while following the principles of surgical oncology in hilar cholangiocarcinoma.

Key words: right hepatectomy, perihilar cholangiocarcinoma

\section{Introduction}

The goal of providing radical and curativeintent surgical treatment to patients with perihilar cholangiocarcinoma (PHC) has led to the definition of standard requirements to be fulfilled in surgical candidates including: biliary confluence resection combined with major hepatectomy, along with resection of Sg1 and locoregional lymphadenectomy. In order to achieve the aforementioned requirements specific technical complexities need to be addressed, with the aim of both providing an oncologically adequate treatment and controlling the still high risk of postoperative morbidity and mortality. In this scenario, adoption of minimally invasive surgery (MIS) in the context of PHC has been traditionally considered a taboo (1). However, MIS has gained field and importance in the world of liver surgery, thanks to documented advantages over the open approach (2): in fact recently several technical limitations have been overcome, increasing the progressive growth of indications with an acquired profile of technical complexity (3).

In previous studies from our group $(1-4,5)$, the feasibility and reproducibility of MIS for PHC are reported: within centers with adequate expertise and respecting the cornerstones of oncological adequacy, the application of open surgery standards is guaranteed (4-6). The video reports the case of a patient with PHC involving the right biliary duct and requiring right hepatectomy with biliary confluence and segment 1 resection, with associated lymphadenectomy.

\section{Preoperative Evaluation}

The patient presented in a peripheral center with jaundice and underwent radiological staging through a chest and abdomen CT scan with contrast enhancement and MRI with gadoxetic acie to evaluate the extent of the local disease, both in terms of longitudinal (biliary involvement) and radial (vascular involvement) extension. At preoperative evaluation, biliary disease predominantly involved the right hemiliver with involvement of the right hepatic artery. The patient was then referred to us after the placement of right external-internal biliary drainage. Data regarding clinical and radiological evaluation were discussed during the multidisciplinary hepatobiliary meeting and the patient was candidate to surgery since there were no technical contraindications or criteria for irresectability met. In order to obtain an adequate oncological radicality, a right hepatectomy extended to Sg1 was planned and performed without the need to induce hypertrophy of the left hemiliver since the future liver remnant (FLR) had adequate volume and function (Volume FLR: 39\%; functional evaluation at Technetium $99 \mathrm{~m}$ Tc mebrofenin scintigraphy: $2.81 \% / \mathrm{min} / \mathrm{m}^{2}$ with cutoff $\left.2.69 \% / \mathrm{min} / \mathrm{m}^{2}\right)$.

\section{Surgical Technique}

The patient was placed in the French surgical position, with both arms and legs apart. The first operator was standing between the patient's legs, the first assistant to the right of the operator and the camera holder to the left. 
The first trocar was positioned along the right mid-clavicular line and, under $4 \mathrm{~K}$ view, four other 10-12 $\mathrm{mm}$ accesses were placed in the configuration of an inverted $\mathbf{J}$ (respectively in the supraumbilical position, on the right flank, in the epigastrium and in the left ipocondrium). The first step involved the formal lymphadenectomy for the removal of the lymph nodes of stations 8 and 12. The hepatic hilum was loaded on an umbilical tape for the Pringle maneuver which is normally performed with an extracorporeal technique (also allowing the first assistant to handle the chest tube from the outside, in case of need). The main bile duct was isolated, dissected in its extrapancreatic portion and sent for histological frozen section examination. A primary hilar approach was used in this case, consisting of separate dissection and extraparenchymal isolation of the right hepatic artery and right portal vein. The anterior approach without hepatic mobilization is preferentially performed when facing a right hepatectomy in our center. Parenchymal transection was performed along the ischemic demarcation line (corresponding to the Cantlie line) through the combined use of ultrasound dissector, wet bipolar forceps, and energy devices. The hilar plate was reached via transparenchymal route and the bile duct contralateral to the disease (therefore the left) was sectioned sending the stump is sent for intraoperative frozen section to rule out neoplastic infiltration. Segment 1 was removed as well, to control locoregional disease spread. A short midline incision was used to retrieve the resected specimen and to perform the biliary enteric anastomosis.

\section{Results}

Conversion to the open approach was not required. Intraoperative frozen sections on the distal and proximal margins revealed $\mathrm{R} 0$ status on both margins. The length of procedure was 400 minutes. 13 lymph nodes (6 from station 8 and 7 from station 12) were retrieved and the final pathologic examination revealed presence of neoplastic infiltration in 1 out of 13 nodes. Pringle maneuver was applied 7 times for a total duration of 75 minutes. The patient developed a low volume biliary fistula (Dindo II) and ascites (Dindo II) requiring treatment with intravenous diuretics and albumin administration. Postoperative length of stay was 13 days. Final pathological staging was adenocarcinoma with moderate differentiation (G2), pT3 (with vascular and perineural involvement), $\mathrm{pN} 1$ (1/13).

\section{Conclusion}

The magnification of images provided by minimally-invasive approach allows a very sharp and precise dissection of the hilum, together with the possibility of specifically recognize the structures of the hepatic pedicle and exclude vascular infiltration by radial disease spread (7). Nevertheless, MIS for PHC should be completed only in expert centers, with an adequate expertise both in the mana-gement of patients with bliary tumors allowing a tailored perioperative management (8) and in minimally invasive resection with an high degree of technical complexity. Current results, together with feasibility and reproducibility of the technique shown in the present video, appear promising and constitute a good prerequisite for the further implementation of this approach to improve patients outcome.

\section{Author's Contributions}

The material has not been previously published or submitted elsewhere for publication and will not be sent to another journal until a decision is made concerning publication. All listed authors have participated in the study and have approved the final manuscript.

\section{Conflict of Interest}

The authors declare no conflicts of interests.

\section{References}

1. Ratti F, Fiorentini G, Cipriani F, Catena M, Paganelli M, Aldrighetti L. Perihilar cholangiocarcinoma: are we ready to step towards minimally 
invasiveness? Updates Surg. 2020;72(2):423-433.

2. Aldrighetti L, Ratti F, Cillo U, Ferrero A, Ettorre GM, Guglielmi A, et al. Diffusion, outcomes and implementation of minimally invasive liver surgery: a snapshot from the I Go MILS (Italian Group of Minimally Invasive Liver Surgery) Registry. Updates Surg. 2017;69(3):271-283.

3. Aldrighetti L, Cipriani F, Fiorentini G, Catena M, Paganelli M, Ratti F. A stepwise learning curve to define the standard for technical improvement in laparoscopic liver resections: complexity-based analysis in 1032 procedures. Updates Surg. 2019;71(2):273-283.

4. Ratti F, Fiorentini G, Cipriani F, Catena M, Paganelli M, Aldrighetti L. Technical Insights on Laparoscopic Left and Right Hepatectomy for Perihilar Cholangiocarcinoma. Ann Surg Oncol. 2020;27(13):5191-5192.

5. Ratti F, Casadei-Gardini A, Cipriani F, Fiorentini G, Pedica F, Burgio V, Cascinu S, Aldrighetti L. Laparoscopic Surgery for Intrahepatic Cholangio-carcinoma: A
Focus on Oncological Outcomes. J Clin Med. 2021; 10(13):2828.

6. Ratti F, Fiorentini G, Cipriani F, Paganelli M, Catena M, Aldrighetti L. Perioperative and Long-Term Outcomes of Laparoscopic Versus Open Lymphadenectomy for Biliary Tumors: A Propensity-Score-Based, CaseMatched Analysis. Ann Surg Oncol. 2019;26(2):564-575.

7. Ratti F, Cipriani F, Piozzi G, Catena M, Paganelli M, Aldrighetti L. Comparative Analysis of Left- Versus Right-sided Resection in Klatskin Tumor Surgery: can Lesion Side be Considered a Prognostic Factor? J Gastrointest Surg. 2015;19(7):1324-33.

8. Ratti F, Cipriani F, Fiorentini G, Hidalgo Salinas C, Catena M, Paganelli M, et al. Management of hilum infiltrating tumors of the liver: The impact of experience and standardization on outcome. Dig Liver Dis. 2019;51(1):135141. Epub 2018 Jul 17. 